\title{
Influence of Genotypes, Season of Birth, Parity Order and the Interactions between Them on Litter Traits and Body Weight Measurements of Rabbits
}

\author{
Desouky, A. T ${ }^{1 *}$; EL-Gendi, G. $M^{1}$; Iraqi, M. $M^{1}$ and Rashad, S. $A^{2}$ \\ ${ }^{1}$ Animal Production Dept., Fac. of Agric., Benha Univ., Egypt. \\ ${ }^{2}$ Agricultural Economics Dept., Fac. of Agric., Benha Univ., Egypt. \\ * Corresponding author: alaadesouky85@gmail.com
}

\begin{abstract}
The aim of current study was to investigate the effects of the effect of genotype, season of birth and parity order on litter traits and body weight measurements of V-line and Moshtohor line (M-line) of rabbits. A total number of six thousand and three hundreds (6300 kits) offspring obtanid from these strains (100 sires and 300 dams) were used in this study. The body weight traits were recorded at 4, 8 and 12 weeks of age. Litter size at birth (LSB), Litter size at weaning at 28 days postnatal (LSW), Litter weight at birth (LWB), Litter weight at weaning at 28 days postnatal (LWW), Mortality rate and killing intervals. The effect of genotype showed that Mline revealed significant superiority $(\mathrm{P}<0.05)$ value of the body weight at all periods of estimation compared to $\mathrm{V}$-line breeds. Also, the effect of season showed a significant $(\mathrm{P}<0.05)$ change in the body weight at all periods of estimation due to season's effect. The heaviest live body weight was recorded for rabbits in springe, while the lowest live body weight was recorded in summer. Influence of parity indicated highly significant $(P<0.05)$ differences in body weight in different intervals of age. The heaviest body weight was recorded in the third parity, while the lowest body weight was recorded in first parity. Likewise, the present study revealed a Highly significant $(\mathrm{P}<0.05)$ difference were deleted in the litter size and at birth and weaning, litter weight at birth and at weaning between the different genotype, season and parity order. It can be concluded that M-line had the highest values of live body weight and litter traits compared to V-line rabbits. Current study finding suggest that M-line rabbits will be more productive and reproductive efficiency than V-line rabbit under Egyptian environmental conditions. So, the authors suggest that measuring of body weight and litter traits early ages could be a good and accurate indicator of growth performance in M-line.
\end{abstract}

Key words: Genotype, season, Litter size, litter weight, body weight, Rabbits.

\section{Introduction}

Rabbits, as opposed to other farm animals, have a high capacity for producing a significant amount of meat. As a result, rabbits can be a good source of inexpensive animal protein in developing countries. Rabbit meat is a low-cost source of meat that is high in protein, low in calories, and low in fat and cholesterol. (Dalle Zotte, 2002 and Ajayi et al., 2018). Litter weight at weaning is controlled by the number of survived kits at weaning (Risam et al., 2005 and Ahmed et al., 2005). The individual birth weight is observed to decrease with an increase in the size of the litter. Rabbit Kits of larger litters usually have a lower weight at weaning than the corresponding weight for smaller litter kits (Poigner et al., 2000). This is due to the fact that their body weight gain depends on milk intake. Does milk production is also positively related to litter size (Ayyat et al., 1995 and El-Attrouny and Habashy, 2020).

The influence of the season on the reproductive performance of rabbits could differ in does and in growing rabbits. Choudhary et al. (2001) showed that the seasons had strong influence on kindling interval and litter weight at weaning. Bhatt et al. (2002) found that litter size and weight at birth, litter size at weaning as well as litter weight at weaning were all higher during winter as compared to those during the summer season. Litter size at birth was found to be lowest during summer and highest during winter (Ayyat and Marai, 1998 and Habeeb et al., 1999).

Body weight is known to be highly heritable and hence the selection of heavier animals in a population should be as a result of genetic improvement of the traits (Garcia et al., 2000; El-Attrouny et al., 2017 and El-Attrouny et al., 2020). According to Castellini et al., 2003, the post birth bodyweight of rabbit kits is significantly influenced by litter size at birth due to the fact that the relative share of milk per kit decreased as the litter size increased. The objective of the following study was to evaluate the effect of genotype, season, and parity order on litter size and body weight measurements of rabbits at pre-weaning and postweaning stages.

\section{Materials and Methods}

\section{Location and experimental period}

The experimental work of this study was carried out within a project of "Development of livestock in the village" - Intensification and production of genetically enhanced rabbit in MEET KENANA village Qalyoubia (application form) - in cooperation with the Bank of Misr for development and community service through four successive seasons from 2012 to 2013. 


\section{Experimental Animals}

The used animals in this experiment were M-line and V-line. M- Line was synthesized in the Department of Animal Production, Faculty of Agricultures, Moshtohor, Benha University, Egypt (Iraqi et al., 2008). The breeding program of M- line was conducted by crossing Sinai Gabali rabbits bucks (S) with V-line does (V) followed by selection for LWW in three subsequent generations and after F3. Consequently, this line is formed from $50 \%$ Sinai Gabali and $50 \% \mathrm{~V}$ line $(1 / 2 \mathrm{~S} 1 / 2 \mathrm{~V})$ where selection was practiced for LWW and individual weight at $56 \mathrm{~d}$ and the animals were kept in the rabbitry of Benha University. The V-line is a maternal line selected for LSW by Animal Science Department, Universidad Politécnica de Valencia, (UPV), Valencia, and Spain. A total number of six thousand and three hundreds progenies generated from two breeds were used for this experiment. Total number of three hundreds does (i.e. $150 \mathrm{~V}$-line and $150 \mathrm{M}$-line) and one hundred bucks (50 V-line and $50 \mathrm{M}$-line) were used in the experiment.

\section{Housing and Feeding}

Breeding bucks and does were housed separately individual in wired cages with standard dimensions (60 x $40 \times 35 \mathrm{~cm}$, length $\mathrm{x}$ width $\mathrm{x}$ height) in a flat dick batteries. In rabbitry, temperature ranged from 15 to $35^{\circ} \mathrm{C}$, the relative humidity ranged from 30 to $70 \%$ and photoperiod was at $16 \mathrm{~L}: 8 \mathrm{D}$. Each maternity cage was supplied with a galvanized steel nest boxes. Cages and nest boxes were cleaned and disinfected regularly after each kindling. Urine and feces dropped from cages on the building floor were cleaned every day morning.

The experimental buck: doe ratio was 1:5 by using natural mating. Each doe was transferred to the assigned buck to be mated and returned back again to her own cage. On the day 10 post mating, each doe was palpated to detect pregnancy. Doe that was not pregnant would returned to the same mating buck to be remated and returned every other day thereafter until a service was observed. Likewise, does were remating after kindling by the same assigned buck.

On the $25^{\text {th }}$ day of pregnancy, the nest boxes were supplied with thick layer of rice straw, which was placed in the bottom of the nest box to help the doe in preparing a worm comfortable nest for her bunnies. Litters born were examined and recorded for, LSB within 12 hours after kindling; litters were checked and examined each morning during the suckling period to remove the dead young. Bunnies were weaned at 28 days post kindling, sexed and transferred to standard progeny wire cages.

The breeding animals were fed ad libitum all over the experimental period on a pelleted commercial ration; pellets were cylindrical in form $(1-2 \mathrm{~cm}$ in length and $0.4 \mathrm{~cm}$ in diameter). The ration was composed of $23 \%$ barley, $19 \%$ wheat bran, $24 \%$ soybean meal , $21 \%$ berseem hay, $13 \%$ yellow corn, $1 \%$ limestone, $0.5 \%$ table salt, $14 \mathrm{~kg}$ di-calcium phosphate/ton, $1 \mathrm{~kg}$ minerals mixture/ton, $1 \mathrm{~kg}$ anticoccidian/ton, $1 \mathrm{~kg}$ anti-toxicity/ton, provided $18.01 \%$ crude protein, $13.7 \%$ crude fiber and $2.5 \%$ fat (digestible energy $=2600 \mathrm{kc} / \mathrm{kg}$ feed according to NRC (1977). All growing and breeding rabbits were kept under the same managerial, hygienic and environmential contions. Fresh drinking water was available all the time.

\section{Data Collection}

Data were recorded for individual rabbits body weights (BW) in two genetic groups (M-line and Vline) at 4,8 and 12 weeks of age, daily weight gains (DG) were calculated during the age intervals from 48, 8-12 and 4-12 weeks of age, Litter traits studied include: Litter size at birth (LSB), litter size at weaning at 28 days postnatal (LSW), litter weight at birth (LWB) and litter weight at weaning at 28 days postnatal (LWW).

\section{Statistical analysis}

Analysis of variance of Two-way ANOVA was carried out using SAS procedure guide (SAS, 2004). According to the following liner model:

$\mathrm{Y}_{\mathrm{ijk}}=\mu+\mathrm{B}_{\mathrm{i}}+\mathrm{S}_{\mathrm{j}}+\mathrm{P}_{\mathrm{k}}+(\mathrm{BS})_{\mathrm{ij}}+\mathrm{e}_{\mathrm{ijkl}}$

Where: $Y_{i j k}=$ the observation of traits for $i j k^{\text {th }}$ buck and doe rabbit; $\mu=$ general mean, common element to all observations; $\mathrm{Bi}=$ the fixed effect of the $i^{\text {th }}$ breed group. $S_{j}=$ the fixed effect of the $j^{\text {th }}$ season. $P_{k}=$ the fixed effect of the $\mathrm{k}^{\text {th }}$ parity $(\mathrm{BS})_{\mathrm{ij}}=$ the fixed effect of the interaction between the $i^{\text {th }}$ breed Group and the $j^{\text {th }}$ season; $\mathrm{e}_{\mathrm{ijkl}}=$ random error associated with the individual observation.

\section{Results and discussion}

\section{Live body weight \\ Effect of breed}

Results in Table 1 showed that M-line had the highest significant estimates of $(\mathrm{P}<0.05)$ body weight at all periods of estimation compared with $\mathrm{V}$-line breeds. This may be due to differences in genetic make-up of the two lines. These results are in agreement with the same trend obtained by Afifi et al. (2000); Iraqi (2003) and Badr et al. (2019).

\section{Seasonal effect}

The present study (Table, 1) showed a significant $(\mathrm{P}<0.05)$ change in the body weight at all periods of estimation due to seasons effect. The heaviest live body weight $(653,1682$, and $2381 \mathrm{~g}$ at 4,8 and $12 \mathrm{wks}$ of age, respectively) were recorded for rabbits in springe, while the lowest live body weights were recorded in summer $(442,1443$ and $2092 \mathrm{~g}$ for 4, 8 and 12 wks of age, respectively). Such difference in body weight might be related to changes in nutrition during winter (green food), climate of summer as well 
as to differences in losses during month of suckling period (Afifi and Khalil, 1990 and Youssef, 1992). The majority of investigators indicated that the lowest performance was observed during the summer season, while the highest values of body weight at different ages were recorded in springs and winter seasons (Enab et al., 2000; Abd El-Aziz et al., 2002 and Saleh et al., 2005). Afifi and Emara (1990) attributed the differences caused by year of birth effects on post- weaning daily gain to the annual changes in climate, management, feeding and disease conditions which might vary from one year to another. Generally, the dissimilarity among seasons in body weight traits could be attributed to the decreased feed intake, depression of thyroid activity and hence in the metabolic rate of pregnant does during hot summer months affected body weight weight negatively (Abdel-Azeem et al., 2007).

Table 1. Least-square means and standard error $(X \pm S . E)$ for body weight of rabbits of different experimental groups as affected by studied factors.

\begin{tabular}{lccc}
\hline & & Life body weight $(\mathrm{g})$ at & \\
\cline { 2 - 4 } Item & BW4 & BW8 & \\
\hline Breed (B) & & & $2256 \pm 14.7^{\mathrm{b}}$ \\
\hline V-line & $578 \pm 4.1^{\mathrm{b}}$ & $1566 \pm 10.6^{\mathrm{b}}$ & $2378 \pm 15.4^{\mathrm{a}}$ \\
M-line & $631 \pm 4.3^{\mathrm{a}}$ & $1682 \pm 11.1^{\mathrm{a}}$ & \\
Season ( S ) & & & $2250 \pm 34.4 \mathrm{c}$ \\
Autum & $551 \pm 9.6^{\mathrm{c}}$ & $1549 \pm 24.7^{\mathrm{c}}$ & $2356 \pm 19.6 \mathrm{~b}$ \\
Winter & $638 \pm 5.4^{\mathrm{b}}$ & $1660 \pm 14.0^{\mathrm{b}}$ & $2381 \pm 22.4 \mathrm{a}$ \\
Springe & $653 \pm 6.2^{\mathrm{a}}$ & $1682 \pm 16.1^{\mathrm{a}}$ & $2092 \pm 39.5 \mathrm{~d}$ \\
Summer & $442 \pm 11^{\mathrm{d}}$ & $1443 \pm 28.4^{\mathrm{d}}$ & \\
Parity (P) & & & $2249 \pm 33.4^{\mathrm{b}}$ \\
First & $566 \pm 9.3^{\mathrm{c}}$ & $1568 \pm 23.9^{\mathrm{b}}$ & $2344 \pm 26.9^{\mathrm{a}}$ \\
Second & $633 \pm 7.5^{\mathrm{b}}$ & $1653 \pm 19.3^{\mathrm{a}}$ & $2387 \pm 23.8^{\mathrm{a}}$ \\
Third & $652 \pm 6.6^{\mathrm{a}}$ & $1684 \pm 17.3^{\mathrm{a}}$ & $2251 \pm 25.2^{\mathrm{b}}$ \\
Fourth & $561 \pm 7.0^{\mathrm{c}}$ & $1573 \pm 18.1^{\mathrm{b}}$ & \\
Interaction (B X S) & & & $2227 \pm 29.3 \mathrm{bc}$ \\
V X Autum & $529 \pm 8.2 \mathrm{~d}$ & $1521 \pm 20.9 \mathrm{~cd}$ & $2294 \pm 20.4 \mathrm{~b}$ \\
V X Winter & $613 \pm 5.7 \mathrm{~b}$ & $1604 \pm 14.5 \mathrm{~b}$ & $2305 \pm 24.0 \mathrm{~b}$ \\
V X Springe & $625 \pm 6.7 \mathrm{~b}$ & $1600 \pm 17.1 \mathrm{~b}$ & $2029 \pm 39.9 \mathrm{~d}$ \\
V X summer & $411 \pm 11.2 \mathrm{f}$ & $1409 \pm 28.4 \mathrm{e}$ & $2270 \pm 27.8 \mathrm{~b}$ \\
M X Autum & $570 \pm 7.8 \mathrm{c}$ & $1575 \pm 19.8 \mathrm{bc}$ & $2437 \pm 23.4 \mathrm{a}$ \\
M X Winter & $671 \pm 6.5 \mathrm{a}$ & $1733 \pm 16.7 \mathrm{a}$ & $2465 \pm 25.5 \mathrm{a}$ \\
M X Springe & $684 \pm 7.1 \mathrm{a}$ & $1774 \pm 18.1 \mathrm{a}$ & $2170 \pm 44.6 \mathrm{c}$ \\
M X Summer & $480 \pm 12 \mathrm{e}$ & $1485 \pm 31.8 \mathrm{~d}$ &
\end{tabular}

$\overline{a, b, c}$ Means with different superscript in the same column are significantly different at $(\mathrm{P}<0.05)$.

BW4, body weight at 4 weeks; BW8, body weight at 8 weeks; BW12, body weight at 12 weeks of age.

\section{Parity effect}

Data presented in Table (1) indicated highly significant $(\mathrm{P}<0.05)$ differences in body weight in different intervals of age. The heaviest body weight (652, 1684, and $2387 \mathrm{~g}$ ) was recorded in the third parity at 4, 6 and 12 wks, respectively. While the lowest body weight was recorded in first parity (566, 1568 and $2249 \mathrm{~g}$ at 4,8 and $12 \mathrm{wks}$, respectively). The results obtained agree with the same trend reported by Youssef (1992); Abd El-Raouf (1993) and Afifi et al. (1994) who revealed a general trend indicating that body weight at different ages increased with advance of parity till reaching its maximum at a certain parity and decreased thereafter. Also, other studies revealed an inconsistent trend for the effect of parity on body weight (Hanna, 1992; Tag El-Din et al., 1992 and Afifi et al., 2000).

\section{The interaction between breed and season}

Data presented in table, 1, revealed a highly significant $(\mathrm{P}<0.05)$ effect due to the interaction between the breed and season on body weight of rabbits. The heaviest body weight recorded by M-line in springe $(684,1774$ and $2465 \mathrm{~g}$ at 4,8 and $6 \mathrm{wks}$, respectively) and the lowest average of body weight was observed in the V-line breed in summer (411, 1409 and $2029 \mathrm{~g}$ at 4, 8 and 6 wks of age, respectively). This finding support that observed in some previous investigations by Afifi et al., 2000 and Abd El-Halim, 2003, with New Zealand White (NZW), Gabali and Californian (CAL) rabbits and their crosses, indicating the presence of a significant $(\mathrm{p}<0.05))$ seasonal effect on kindling interval. However, a non-significant effect for season of kindling on day's open, kindling interval and insemination period was noticed with NZW, Baladi Red rabbits and their crosses (Khalil, 1993; Khalil et al., 1995 and Ahmed, 1997) with NZW rabbits

Daily weight gain

Effect of breed 
As shown in table, 2, the present study revealed significant $(\mathrm{P}<0.05)$ difference in the body weight gain among breeds at the period from $4-8$ wks only. The highest means of daily gain during periods from 4-8, 8-12 and 4-12weeks of age were in M-line found recording (35.0, 23.2 and 29.1, respectively). Also, it was recorded 32.9, 23.0 and $27.95 \mathrm{~g}$ /day for V-line during the periods from 4-8, 8-12 and 4-12 wks, respectively. These results are in agreement with the same trend obtained by Afifi et al., 2000 and Iraqi, 2003.

\section{Seasonal effect}

Results in Table 2 showed non-significant $(\mathrm{P}<0.05)$ change, in body weight gain, different intervals between the different seasons. The best weight gains (34.3, 23.3, and $28.80 \mathrm{~g}$ day) were recorded during the periods from $4-8,8-12$ and 4 - 12, wks of rabbits age in springe respectively, However the lowest weight gains, $(33.3,21.6$ and $27.5 \mathrm{~g} /$ day) during the periods from 4-8, 8-12 and 4-12 wks, respectively in summer. Afifi and Emara (1988 and 1990) attributed the differences caused by year of birth effects on postweaning daily gain to the annual changes in climate, management, feeding and disease conditions which might vary from one year to another.

Table2. Least-square means and standard error $(\mathrm{X} \pm \mathrm{S}$.E $)$ for daily weight gain of rabbits of different experimental groups as affected by studied factors.

\begin{tabular}{|c|c|c|c|}
\hline \multirow[t]{2}{*}{ Item } & \multicolumn{3}{|c|}{ daily weight gain $(\mathrm{g})$ during } \\
\hline & DG4-8 & DG8-12 & DG4-12 \\
\hline \multicolumn{4}{|l|}{ Breed ( B ) } \\
\hline V-line & $32.9 \pm 0.23^{\mathrm{b}}$ & $23.0 \pm 0.18^{\mathrm{a}}$ & $27.95 \pm 0.23 \mathrm{a}$ \\
\hline M-line & $35.0 \pm 0.24^{\mathrm{a}}$ & $23.2 \pm 0.19^{\mathrm{a}}$ & $29.10 \pm 0.23 \mathrm{a}$ \\
\hline \multicolumn{4}{|l|}{ Season ( S ) } \\
\hline Autum & $33.2 \pm 0.55 \mathrm{a}$ & $23.3 \pm 0.43^{\mathrm{a}}$ & $28.31 \pm 0.43 \mathrm{a}$ \\
\hline Winter & $34.0 \pm 0.31 \mathrm{a}$ & $23.2 \pm 0.24 \mathrm{a}$ & $28.62 \pm 0.43 \mathrm{a}$ \\
\hline Springe & $34.3 \pm 0.36 \mathrm{a}$ & $23.3 \pm 0.28 \mathrm{a}$ & $28.80 \pm 0.43 \mathrm{a}$ \\
\hline Summer & $33.3 \pm 0.63 \mathrm{a}$ & $21.6 \pm 0.50 \mathrm{~b}$ & $27.50 \pm 0.43 b$ \\
\hline \multicolumn{4}{|l|}{ Parity ( P ) } \\
\hline First & $33.4 \pm 0.53^{\mathrm{b}}$ & $23.3 \pm 0.42^{\mathrm{a}}$ & $28.38 \pm 0.43 \mathrm{ab}$ \\
\hline Second & $34.0 \pm 0.43^{\mathrm{ab}}$ & $23.0 \pm 0.34^{\mathrm{ab}}$ & $28.50 \pm 0.43 \mathrm{ab}$ \\
\hline Third & $34.3 \pm 0.38^{\mathrm{a}}$ & $23.4 \pm 0.30^{\mathrm{a}}$ & $28.91 \pm 0.43 a$ \\
\hline Fourth & $33.7 \pm 0.40^{\mathrm{ab}}$ & $22.5 \pm 0.32^{\mathrm{b}}$ & $28.16 \pm 0.43 b$ \\
\hline \multicolumn{4}{|l|}{ Interaction $(\mathrm{B} * \mathrm{~S})$} \\
\hline V X Autum & $33.0 \pm 0.45 b$ & $23.5 \pm 0.37 \mathrm{a}$ & $28.30 \pm 0.37 b$ \\
\hline V X Winter & $33.0 \pm 0.32 b$ & $23.0 \pm 0.25 \mathrm{a}$ & $28.01 \pm 0.37 b c$ \\
\hline V X Springe & $32.4 \pm 0.37 b$ & $23.5 \pm 0.30 \mathrm{a}$ & $28.01 \pm 0.37 b c$ \\
\hline V X summer & $33.0 \pm 0.62 \mathrm{a}$ & $20.6 \pm 0.50 b$ & $26.96 \pm 0.37 c$ \\
\hline M X Autum & $33.4 \pm 0.43 a$ & $23.1 \pm 0.35 \mathrm{a}$ & $28.31 \pm 0.37 b$ \\
\hline M X Winter & $35.3 \pm 0.36 a$ & $23.4 \pm 0.29 a$ & $29.43 \pm 0.37 \mathrm{a}$ \\
\hline M X Springe & $36.3 \pm 0.39 a$ & $23.7 \pm 0.32 \mathrm{a}$ & $29.69 \pm 0.37 a$ \\
\hline M X Summer & $33.5 \pm 0.69 b$ & $22.8 \pm 0.56 b$ & $28.17 \pm 0.37 b$ \\
\hline
\end{tabular}

\section{Parity effect}

Data presented in Table (2) showed a significant $(\mathrm{P}<0.05)$ difference in the body weight gains at different intervals of age. The highest body weight gain $(34.3,23.40$, and $28.90 \mathrm{~g} /$ day) were recorded in third parity at 4-8, 8-12 and 4-12 wks, respectively, while the lowest weight gains $(33.4,23.3$ and $28.38 \mathrm{~g} /$ day) were recorded in first parity during the periods from 4-8, 8-12 and 4-12 wks, respectively. These results are in agreement with the same trend obtained by Abd El-Raouf (1993) and Afifi et al., (1994) who revealed a general indicating that body weight at different ages increased with advance of parity till reaching its maximum at certain parity and decreased thereafter. Also, other studies revealed an inconsistent trend for the effect of parity on body weight (Khalil and Afifi1987 and Afifi et al., 2000).

\section{The Interaction between breed and season}

Table, 2 results revealed a significant $(\mathrm{P}<0.05)$ effect of the interaction between the breed and season on the body weight gains. The best body weight gains recorded by M-line in springe (table 2 ) at the periods from 4-8, 8-12 and 4-12 wks, respectively) and the lowest weight gains were observed in the V-line breed in summer (table 2) during the periods from 4-8, 8-12 and 4-12 wks, respectively. These findings are consistent with that observed in some previous investigations (Afifi et al., 2000 and Abd El-Halim, 2003.). 


\section{Litter traits \\ Litter size \\ Effect of breed}

Table, 3 showed no significant $(\mathrm{P}<0.05)$ effect in the litter size at birth due to the breed genotype. The highest LSB (6.6) was found in M-line, while the lowest (6.3) was observed in V-line. However breed effect has highly significant effect on LSW. M-line had the higher LSW (6.03) compared with V- line which showed the lowest litter size.

Significant $(\mathrm{P}<0.05)$ difference was indicated in the number of mortality at weaning between the different breeds. The highest value was 1.04 in M-line and the lowest (0.96) was observed in V-line. The litter size varied from 5.26 to 5.62. Previous studies emphasized the breed effect on the litter size (Enab et al., 2000 and Iraqi et al., 2010). This effect might be attributed to the higher ovulation rate, better milk secretion and lower pre-weaning mortality rates as well as the suitability of environmental conditions for some breeds more than others (El-Badawy, 2004). the experiments on or the investigation on NZW, Gabali rabbits and their crosses (Abd El-Aziz, 1998), NZW and CAL rabbits (Afifi et al., 2000) and with NZW and Baladi Red rabbits (Abd El-Halim, 2003), revealed that there were a significant $(\mathrm{p}<0.01)$ effect, for season of kindling on the kindling interval and the insemination period.

\section{Seasonal effect}

Table 3 in the showed a significant $(\mathrm{P}<0.05)$ difference in the LSB and LSW due to season. The highest value appeared in summer (6.8 and 6.1) and the lowest in summer and autum (6.3 and 5.5). Insignificant $(\mathrm{P}<0.01)$ difference in the LSW was observed between the different seasons. This finding came in agreement with that reported by AbdelAzeem, 2007 where in Baladi Red the highest LSW was recorded in January.

This may be due to the favorable climatic and nutritional conditions as well as to the high milk yield produced during winter months (Khalil, 1993; Pascual et al., 1996 and Abou Khadiga, 2004). The number of mortality at weaning, significantly difference between the different by seasons. The values varied from 0.78 to 1.17. May-June may be attributed to effects of the high ambient temperature that results in a reduction in the quantity of feed consumption of does (Sallam et al., 1999 and Garcia et al., 2000). From the previously mentioned results it could be stated that the season of kindling is considered one of the most important nongenetic factors affecting productive rabbit does (ElMaghawry, 1999). Many studies suggested that the effect of season of kindling on litter size is a reflection to the climatic seasonality as well as to the availability and quality of diets (Youssef, 1992; Abd EL-Aziz, 1998 and Garcia et al., 2000).

Table 3. Effect of breed, season and parity on litter size at birth (LSB), litter size at weaning (LSW), and mortality at weaning (MORT.), in rabbits.

\begin{tabular}{|c|c|c|c|}
\hline Item & LSB & LSW & MORT \\
\hline \multicolumn{4}{|l|}{ Breed (B) } \\
\hline V-line & $6.3 \pm 0.17^{\mathrm{a}}$ & $5.31 \pm 0.16^{\mathrm{b}}$ & $0.96 \pm 0.14^{\mathrm{ab}}$ \\
\hline M-line & $6.6 \pm 0.18^{a}$ & $6.03 \pm 0.17^{\mathrm{a}}$ & $1.04 \pm 0.12^{\mathrm{a}}$ \\
\hline \multicolumn{4}{|l|}{ Season ( S ) } \\
\hline Autum & $6.4 \pm 0.40^{\mathrm{b}}$ & $5.5 \pm 0.39^{b}$ & $0.88 \pm 0.14^{\mathrm{a}}$ \\
\hline Winter & $6.8 \pm 0.23^{\mathrm{a}}$ & $6.1 \pm 0.22^{\mathrm{a}}$ & $0.78 \pm 0.11^{\mathrm{a}}$ \\
\hline Springe & $6.6 \pm 0.26^{\mathrm{a}}$ & $5.6 \pm 0.25^{\mathrm{b}}$ & $0.97 \pm 0.12^{\mathrm{a}}$ \\
\hline Summer & $6.3 \pm 0.46^{\mathrm{b}}$ & $5.5 \pm 0.45^{\mathrm{b}}$ & $1.17 \pm 0.12^{\mathrm{b}}$ \\
\hline \multicolumn{4}{|l|}{ Parity (P) } \\
\hline First & $6.4 \pm 0.39^{a}$ & $5.6 \pm 0.38^{\mathrm{a}}$ & $0.87 \pm 0.21^{\mathrm{b}}$ \\
\hline Second & $6.6 \pm 0.31^{\mathrm{a}}$ & $5.5 \pm 0.30^{\mathrm{a}}$ & $1.11 \pm 0.21^{\mathrm{a}}$ \\
\hline Third & $6.6 \pm 0.28^{\mathrm{a}}$ & $5.7 \pm 0.27^{\mathrm{a}}$ & $0.83 \pm 0.23^{\mathrm{b}}$ \\
\hline Fourth & $6.3 \pm 0.29^{a}$ & $5.7 \pm 0.28^{\mathrm{a}}$ & $0.85 \pm 0.18^{\mathrm{b}}$ \\
\hline \multicolumn{4}{|c|}{ Breed $*$ Season $(B * S)$} \\
\hline V X Autum & $6.0 \pm 0.34^{b}$ & $5.2 \pm 0.33^{\mathrm{b}}$ & $0.9 \pm 0.28^{b}$ \\
\hline V X Winter & $6.7 \pm 0.24^{\mathrm{ab}}$ & $5.9 \pm 0.23^{\mathrm{b}}$ & $0.07 \pm 0.18^{\mathrm{c}}$ \\
\hline V X Springe & $6.4 \pm 0.28^{\mathrm{ab}}$ & $5.2 \pm 0.27^{\mathrm{b}}$ & $0.65 \pm 0.20^{\mathrm{b}}$ \\
\hline V X summer & $6.2 \pm 0.47^{b}$ & $5.6 \pm 0.45^{\mathrm{b}}$ & $1.12 \pm 0.23^{\mathrm{a}}$ \\
\hline M X Autum & $6.6 \pm 0.33^{\mathrm{ab}}$ & $5.9 \pm 0.31^{\mathrm{ab}}$ & $1.1 \pm 0.18^{\mathrm{ab}}$ \\
\hline M X Winter & $7.5 \pm 0.27^{\mathrm{a}}$ & $6.9 \pm 0.26^{\mathrm{a}}$ & $1.82 \pm 0.19^{b}$ \\
\hline M X Springe & $6.4 \pm 0.30^{\mathrm{ab}}$ & $5.8 \pm 0.29^{\mathrm{ab}}$ & $1.6 \pm 0.20^{\mathrm{a}}$ \\
\hline M X Summer & $6.5 \pm 0.53^{b}$ & $5.2 \pm 0.51^{\mathrm{b}}$ & $1.75 \pm 0.17^{\mathrm{a}}$ \\
\hline
\end{tabular}

\section{Parity effect}

Data presented in Table (3) indicated that nonsignificant $(\mathrm{P}<0.05)$ differences in the LSB and LSW were observed between the different parity. The highest values showed in the second and third parity for LSB and the third and fourth parity of LSW. This 
finding came in agreement with that reported by Youssef (1992); Abd El-Raouf (1993) and Afifi et al. (1994) who revealed a general trend indicating that body weight at different ages increased with advance of parity till reaching its maximum at a certain parity and decreased thereafter. Also, other studies revealed an inconsistent trend for the effect of parity on body weight (Khalil et al., 1987; Tag El-Din et al., 1992 and Afifi et al., 2000). Khalil et al. (1993) reported that changes with parity are mostly a reflection of the efficiency of the dam as a mother especially those associated with sustained ability of the lactating dam to suckle her young until weaning.

\section{The effect Interaction between breed and season}

The Interaction between breed and season are presented in (table, 3$)$ revealed a significant $(\mathrm{P}<0.05)$ effect on the LSB and LSW and the number of mortality at weaning. The highest value of LSB and at weaning appeared with the M-line in winter ( $7.5 \&$ 6.9 , resp.) and the lowest values were observed with the V-line in autumn ( $6.0 \& 5.2$, resp.). Interaction effect between breed $\mathrm{x}$ season showed significant effect on mortality rate at weaning, the lowest averages of mortality rate was observed in $\mathrm{V}$ - line $\mathrm{x}$ winter $(0.70 \%)$, While the highest value was observed in M-line $\mathrm{X}$ winter (1.82\%), when compared with different interaction applied. These findings came in agreement with some previous studies indicating the presence of a curvilinear relationship with season of kindling where the litter size seems to decrease during the autumn and increase during the winter and spring and then decrease again during the summer in relation to the breed difference (Ahmed, 1997 and Enab et al.,
2000). On the other hand, the present study came in disagreement with some previous investigations reported that the season of kindling does not significantly affect litter size expressed by LSB, LSW and LWW for the different breeds (Abou-Khadiga, 2004 and Badr et al., 2016).

\section{Litter weight}

\section{Effect of breed}

As shown in (table, 4), the present study revealed a highly significant $(\mathrm{P}<0.05)$ difference in the LWB and LWW between the different breeds. The heaviest weight at birth came with the M-line (629 g) and the lowest weight with the V-line breed (443 g), whereas, the highest LWW appeared with M-line (3793 g) and the lowest with the V-line $(3107 \mathrm{~g})$. Breed effect has significant effect on kindling interval. The higher value was observed in V-line (46.0 days). while the lower value was obtained by M-line (42.7d). These findings came in agreement with some previous investigations of (Enab et al., 2000;) they indicating that the performance of doe was better in some breeds like NZW rabbits than those of local breed. Blasco et al. (1992) and Khalil, (1993) attributed the superiority of NZW rabbits over Cal ones for litter weights to the difference in the ovulation rate, uterine capacity, milk production, and maternal behavior...etc. It can be attribute the improvements of LWB and LWW in Vline rabbit does to the high thyroid activity of this breed. However, the present study came in disagreement with few previous investigators found that the LWB and LWW was not significantly affected by breed (EL-Attrouny and habashy 2020).

Table 4. Effect of breed, season and parity on litter weight at birth (LWB), at weaning in rabbits (LWW) and Kindling interval (KI).

\begin{tabular}{lccc}
\hline \multicolumn{1}{c}{ Items } & LWB $(\mathrm{g})$ & LWW $(\mathrm{g})$ & KI (days) \\
\hline Breed (B) & & & $46.0 \pm 1.1^{\mathrm{a}}$ \\
\hline V-line & $443 \pm 16.8^{\mathrm{b}}$ & $3107 \pm 103^{\mathrm{b}}$ & $42.7 \pm 1.1^{\mathrm{b}}$ \\
M-line & $629 \pm 17.6^{\mathrm{a}}$ & $3793 \pm 108^{\mathrm{a}}$ & \\
Season (S) & & & \\
Autum & $550.1 \pm 39.4^{\mathrm{a}}$ & $3119 \pm 242^{\mathrm{b}}$ & $44.6 \pm 2.6^{\mathrm{a}}$ \\
Winter & $558.4 \pm 22.4^{\mathrm{a}}$ & $3588 \pm 137^{\mathrm{a}}$ & $43.8 \pm 1.5^{\mathrm{a}}$ \\
Springe & $504.8 \pm 25.7^{\mathrm{a}}$ & $3680 \pm 157^{\mathrm{a}}$ & $44.6 \pm 1.7^{\mathrm{a}}$ \\
summer & $529.5 \pm 25.2^{\mathrm{a}}$ & $2758 \pm 277^{\mathrm{b}}$ & $46.0 \pm 3.0^{\mathrm{a}}$ \\
Parity (P) & & & \\
First & $524 \pm 38.1^{\mathrm{a}}$ & $3085 \pm 38.1^{\mathrm{a}}$ & $43.9 \pm 2.5^{\mathrm{a}}$ \\
Second & $540 \pm 30.7^{\mathrm{a}}$ & $3495 \pm 30.7^{\mathrm{a}}$ & $43.7 \pm 2.0^{\mathrm{a}}$ \\
Third & $535 \pm 27.2^{\mathrm{a}}$ & $3365 \pm 27.2^{\mathrm{a}}$ & $45.1 \pm 1.8^{\mathrm{a}}$ \\
Fourth & $521 \pm 28.8^{\mathrm{a}}$ & $2987 \pm 28.8^{\mathrm{a}}$ & $45.1 \pm 1.9^{\mathrm{a}}$ \\
Breed* Season(B*S) & & $44.6 \pm 2.2^{\mathrm{a}}$ \\
V X Autum & & $46.3 \pm 1.6^{\mathrm{a}}$ \\
V X Winter & $417 \pm 33^{\mathrm{c}}$ & $2795 \pm 207^{\mathrm{cd}}$ & $46.0 \pm 1.8^{\mathrm{a}}$ \\
V X Springe & $477 \pm 23^{\mathrm{c}}$ & $3286 \pm 144^{\mathrm{c}}$ & $47.2 \pm 3.0^{\mathrm{a}}$ \\
V X summer & $417 \pm 27^{\mathrm{c}}$ & $3361 \pm 170^{\mathrm{c}}$ & $44.7 \pm 2.1^{\mathrm{a}}$ \\
M X Autum & $432 \pm 45^{\mathrm{c}}$ & $2300 \pm 282^{\mathrm{d}}$ & $40.5 \pm 1.8^{\mathrm{b}}$ \\
M X Winter & $669 \pm 31^{\mathrm{ab}}$ & $3410 \pm 197^{\mathrm{abc}}$ & $43.0 \pm 1.9^{\mathrm{a}}$ \\
M X Springe & $717 \pm 26^{\mathrm{a}}$ & $3983 \pm 165^{\mathrm{ab}}$ & $44.8 \pm 3.4^{\mathrm{a}}$ \\
M X Summer & $603 \pm 29^{\mathrm{b}}$ & $4038 \pm 180^{\mathrm{a}}$ & $3330 \pm 315^{\mathrm{c}}$ \\
\hline a,b, $\ldots$ Means with different superscript with the main factor (breed and season)and their interaction are significantly \\
different (P>0.05) Values are expressed in means \pm SEM. & &
\end{tabular}




\section{Effect of season}

The present study (Table, 4$)$ show a significant $(\mathrm{P}<$ $0.05)$ change in the LWB and at weaning was observed between the different seasons. At birth, the litter weight varied from $504.5 \mathrm{~g}$ in spring to $558.4 \mathrm{~g}$ in winter, while at weaning, it varied from $2758 \mathrm{~g}$ in summer to $3680 \mathrm{~g}$ in winter. Such difference in the litter weight between birth and weaning might be related to changes in nutrition during winter (green food), climate of summer as well as to differences in losses during month of suckling period (Afifi and Khalil, 1990 and Youssef, 1992).The majority of investigators indicated that the lowest performance was observed during the summer season, while the highest values of litter weight and mean bunny weight at different ages were recorded in autumn and winter seasons (Enab et al., 2000, Abd El-Aziz et al., 2002 and Saleh et al., 2005). Generally, the dissimilarity among seasons in litter weight traits could be attributed to the decreased feed intake, depression of thyroid activity and hence in the metabolic rate of pregnant does during hot summer months affected litter weight and mean kit weight at birth negatively (Abdel-Azeem et al., 2007).

\section{Parity effect}

Data presented in Table (3) showed that insignificant $(\mathrm{P}<0.05)$ differences in the LWB, LWW and KI were found due to parity. The heaviest values appeared in the second parity (540.0 and 3495g) and the lowest in the fourth parity (521and $2987 \mathrm{~g}$, respectively). This findings came in agreement with that reported by Youssef (1992); Abd El-Raouf (1993) and Afifi et al. (1994) who revealed a general trend indicating that body weight at different ages increased with advance of parity till reaching its maximum at a certain parity and decreased thereafter. Also, other studies revealed an inconsistent trend for the effect of parity on body weight (Afifi et al., 1990; Hanna, 1992; Tag El-Din et al., 1992 and Afifi et al., 2000). Khalil et al. (1993) reported that changes with parity are mostly a reflection of the efficiency of the dam as a mother (especially those associated with sustained ability of the lactating dam to suckle her young until weaning).

\section{The interaction between breed and season}

Data presented in (table, 4) revealed a highly significant $(\mathrm{P}<0.05)$ effect of the interaction between breed and season on the LWB, at weaning and kindling intervals (Table, 4). The highest LWB appeared with the M-line in winter (717 g) and the lowest appeared with the $\mathrm{V}$-line breed in springe $(417 \mathrm{~g})$, whereas the highest LWW was shown in the M-line breed in springe (4038g) and the lowest in the $\mathrm{V}$-line in summer $(2300 \mathrm{~g})$. This finding came in accordance with some previous investigations (Enab et al., 2000; Afifi et al., 2000; Abou Khadiga, 2004). It has been reported that, in cross breeding group (BB $\mathrm{x} V \mathrm{VL}$ ), the best performance was obtained in autumn with insignificant differences from winter on LWB, while, seasonal effects had no significance on the rest of litter weight traits (Saleh et al., 2005).

\section{Conclusion}

The findings of this study clearly show that genotype, parity, and season have a major effect on rabbit live body weight and litter traits. Based on present research, it can be concluded that $\mathrm{M}$ - line had the highest values of live body weight and litter traits compare to $\mathrm{V}$-line rabbits. Variation in growth rate of rabbit within the same breed or among different breeds could be attributed to environmental factors such as nutrition, season, parity order and management. Similarly, individual birth weight decreases with increase in litter size and rabbit kits of larger litters also showed a lower weight at weaning than the corresponding weight for kits of smaller litters.

\section{References}

Abd EL-Aziz, M. M. (1998). Crossbreeding between Al-Gabali and New Zealand White rabbits in north coast-belt of the Egyptian western desert. Ph. D. Thesis, Faculty of Agriculture, Moshtohor, Zagazig, University, Banha Branch, Egypt.

Abd EL-Aziz, M.M.; Afifi, E.A.; Nayera, Z.B.; Azamal, A.A. and Khalil, M.H. (2002). Genetic evaluation of milk production and litter weight in Gabali, New Zealand White rabbits and their crosses in a newly reclaimed area of Egypt. The $3^{\text {rd }}$ Sci. Conf. On rabbit production in hot climates, Hurghada, Egypt, pp: 103-116.

Abd EL-Halim, H. A. (2003). Comparative studies on the performance of some genotypes of rabbits. M.Sc. Thesis, Faculty of Agriculture, Cairo University, Egypt.

Abd EL-Raouf, H. M. (1993). Genetic studies for some economic traits in rabbits. M. Sc. Thesis, Faculty of Agriculture, Moshtohor, Zagazig University, Benha Branch, Egypt.

Abdel-Azeem, A.S., Abdel-Azim, A.M., Darwish, A.A. and Omar, E.M. (2007) December. Litter traits in four pure breeds of rabbits and their crosses under prevailing environmental conditions of Egypt. In Proc.: 5th International Conference on Rabbit Production in Hot Climate (pp. 4-7).

Abou Khadiga, G.S.M. (2004). Performance of the Spanish synthetic line (V) and the local Baladi Black rabbits and their crosses under Egyptian conditions (Doctoral dissertation, M. Sc. Thesis, Faculty of Agriculture, Kafr El-Sheikh, Tanta University, Egypt).

Afifi, E.A.; Khalil, M.H.; Khadr, A, E. and Youssef, Y.M.K. (1994). Heterosis, maternal and direct effects for post weaning growth traits and carcass performance in rabbits crosses. J. Anim. Breed Genet. 1.11:138-147. 
Afifi, E.A. and Emara, M. E. (1988). Post-weaning viability of purebred and crossbred rabbits under Egyptian conditions. J. Appl. Rabbit. Res., 11(1): 38-41.

Afifi, E.A. and Emara, M.E. (1990). Breed group and environmental factors influencing post weaning daily gain in weight, of purebred and crossbred rabbits. J. Appl. Rabbit. Res. 13:114-11.8.

Afifi, E.A. and Khalil, M.H. (1990). Observations on purebred and crossbred litters of Giza white and grey giant flander rabbits in Egypt. J. Appl. Rabbit Res, 12, pp.273-277.

Afifi, E.A.; Abd EL-Ghany, A.M. and Ahmed, E.G. (2000). Reproductive profile of New Zealand White and California rabbits raised under semiarid environmental conditions. Egypt. Poultry Sci., Vol. 20 (1), March 2000 (145-155).

Ahmed, E. G. A. (1997). Productive performance of different exoic strains of rabbits. Ph.D. Thesis, Faculty of Agriculture, Ismailia, Seuz Canal University, Egypt.

Ahmed, N. A.; Elfar, A. A. and Sakr, O. G. (2005). Evaluation of sexual and maternal behaviour, hormonal pattern and reproductive formance of doe rabbits as affected by seasonal variation. Proceeding 4th International Conference Rabbit Production Hot.

Ajayi, F.O; Ologbose, F.I and Esenowo, E.S. (2018). Influence of Genotypes and Litter Size on Body Weight and Linear Body Measurements of Rabbits. Applied Science Reports, 21(3), pp.8893.

Ayyat, M. S.; Marai, I.F.M. (1998). Evaluation of application of the intensive rabbit production system under the subtropical conditions of Egypt. World Rabbit Sci. 6:213-217.

Ayyat, M. S.; Marai, I. F. M. and EL-Sayiad, G. A. (1995). Genetic and non-genetic factors affecting milk production litter traits of New Zealand White does under Egyptian conditions. World Rabbit Sci. 3(3):119-124.

Badr, O. A.; EL-Shawaf, I.I.S, Khalil, M. H., Refaat, M. H. and El-Zarei, M. F. (2016). Assessment of genetic variability among some rabbit breeds using RAPD-DNA technique. 3rd International Conference on Biotechnology Applications in Agriculture (ICBAA), Benha University, Moshtohor and Sharm El-Sheikh, Egypt. pp. 1-8.

Badr, O.A.M.; El-Shawaf, I.I.S.; Khalil, M.H.A.; Refaat, M.H. and Ramadan, S.I.A. (2019). Molecular genetic diversity and conservation priorities of Egyptian rabbit breeds. World Rabbit Science, 27 (3): 135-141.

Bhatt, R.S.; S.R. Sharma, U.Singh., Kumar.D. and Bhasin V. (2002). Effect of different season on the performance of grey giant rabbits under subtemperate Himalayan conditions. AsianAustralian Journal of Animal Sciences, 15, 812820 .
Blasco, A.; Santacreu V.A.; Thompson R. and Haley, C. S. (1992). Estimates of genetic parameters for ovulation rate, prenatal survival and litter size in rabbits from an elliptical selection. Livestock production Sci. 34, 163-174 .

Castellini C., A. Dal Bosco and C. Mugnai. (2003). Comparison of different reproduction protocol for rabbit does: effect of rabbit production in tropical and sub-tropical agricultural system. J. Amin. Sci., 63: 1581 .

Choudhary, H.; Goswami, R. N., Das D., Das A., Roychoudhury R. (2001). Genetic studies on the reproductive performances of Soviet Chinchilla breed of rabbit under the agro climatic conditions of North Eastern region. Indian J. Anim. Sci., 71, 946-949.

Dalle Zotte, A. (2002). Perception of rabbit meat quality and major factors influencing the rabbit carcass and meat quality. Livestock Production Science, $75: 11-32$.

El-Attrouny, M. M., Iraqi, M. M., Khalil, M. H., and El-Moghazy, G. M. (2017). Genetic and phenotypic evaluation of growth traits in selection experiment performed in synthesized Benha chickens. Annals of Agricultural Science Moshtohor Journal, 51(1), 33-42.

El-Attrouny, M.M. and Habashy, W.S. (2020). Correlated response on litter traits and milk yield in New Zeland white rabbits selected for litter size at birth.Egyptian Poultry Science Journal, 40(3), pp.599-612.

El-Attrouny, M.M., Iraqi, M.M., Sabike, I.I., Abdelatty, A.M., Moustafa, M.M. and Badr, O.A.( 2020). Comparative evaluation of growth performance, carcass characteristics and timed series gene expression profile of GH and IGF-1 in two Egyptian indigenous chicken breeds versus Rhode Island Red. Journal of Animal Breeding and Genetics.

EL-Badawy, F. E. A. (2004). Studies of some productive traits in rabbits. M.Sc. Thesis, Faculty of Agriculture, Cairo University, Egypt.

EL-Maghawry, A.M. (1999). Genetic effects on some doe productivity in New Zealand white and Californian rabbits raised in Egypt. Egyptian. J. Rabbit Sci.,9 (2): 179-195.

Enab, A.A., EL-Weshahy, D.A. and Abdou, F.H. (2000).Genetic analysis of some economic traits in rabbits. Egyptian J. Rabbit. Sci. 10 (2): 327-339.

Garcia, M. L.; Baselga, M. and Peiro, R. (2000). Correlated response on growth traits in a line selected for litter size at weaning. 7th World Rabbit Congress., 389-395.

Habeeb, A.A.M.; Aboul-Naga, A.I and Khadr, A.F. (1999). Deterio ration effect of summer hot climate on bunnies of acclimatized rabbits during suckling period. In: Proceedings of 1 st International Conference on Indigenous Versus Acclimatized Rabbits, El-Arish, North Sinai, Egypt, pp. 253-263. 
Hanna, M. F. S. (1992). Studies on some production traits in rabbits M.Sc. Thesis, Faculty of Agriculture, Moshlohor Zagazig Uni. Banha branch, Egypt.

Iraqi, M. M.; Afifi, E. A.; Baselga, M. Khalil, M. H. and Garcia, M. L. (2008). Additive and heterotic components for post-weaning growth traits in a crossing project of V-line with Gabali rabbits in Egypt. 9th world rabbit Congress. June 10-13, 2008-Verona. Italy.

Iraqi, M.M. (2003). Estimation and evaluation of genetic parameters for body weight traits of New Zealand White rabbits in Egypt using different multivariate animal models. Livestock Research for Rural Development 15 (6).

Iraqi, M.M., García, M.L., Khalil, M.H. and Baselga, M. (2010). Evaluation of milk yield and some related maternal traits in a crossbreeding project of Egyptian Gabali breed with Spanish V-line in rabbits. Journal of Animal Breeding and Genetics, 127(3), pp.242-248.

Khalil, M. H. (1993). Diversity of repeatability between parities for litter traits and reproductive rabbits. World Rabbits Sci., 1(4): 147-154.

Khalil, M.H. and Afifi, E.A. (1987). Doe litter performance of Bauscat and Giza White rabbits, Egyptian, J. Rabbit Sci., 1 (2): 172-184.

Khalil, M.H.; Afifi, E.A. and Youssef, Y.M.K. and Khadr, A.F. (1995). Heterosis, maternal and direct genetic effects for litter performance and reproductive intervals in rabbits crosses. World Rabbit Sci, 3(3): 99-105.

Khalil, M.H.; Soliman, A.M. and Khalil, H.H. (1993). Genetic aspects and litter-size size correction factors for post-weaning growth in New Zealand White and Californian rabbits. Egyptian. J. RabbitSci., 3 (2): 199-217.
NRC (1977). National Research Council. Nutrient Requirements of Domestic Animal. Nutrient Requirements of Rabbits. Washington, U.S.A.

Pascual, J. J.; Cervera, C.; Blas A. and FernanadezCarmona J. (1996). Milk yield and composition in rabbit does using high fat diets. 6th World Rabbit Congress, Toulouse, France. Vol., 1:259-262.

Poigner, J., Szendro, Z., Levai, A., Radnai, I. and Biro-Nemeth, E. (2000). Effect of birth weight and litter size at suckling age on reproductive performance in does as adults. World Rabbit Science, 8(3).

Risam, K.S.; Das, G. K. and Bhasin V. (2005). Rabbit for meat and wool production in India: A review. Indian J. Anim. Sci., 75: 365 - 382.

Saleh, K.; Nofal, R. Y.; Younis, H. and AbouKhadiga, G. (2005). Evaluation of Spanish synthetic line V, Baladi black rabbits and their crosses under Egyptian conditions 3. Individual body weight. The 4th Inter. Con. on Rabbit Prod. In Hot. Clim., Sharm El-Sheikh, Egypt, 3945(2005).

Sallam, M.T., Toson, M. A. and Uohana, B. A. (1999). Effect of crossing Egyptian Local Baladi with New Zealand White rabbits on preweaning litter performance. Egypt. Poult. Sci. Vol 19 (1): March. $71-83$.

SAS Institute (2004): SAS User's Guide. Release 8.2. Ed. SAS Institute Inc. Cary. NC.

Tag EL-Din, L.H.; Ibrahim, Z.M.K. and Oudah, S.M. (1992). Studies on live body weight and litter size in New Zealand White, Californian, Baladi rabbits and their crossbreds in Egypt. Option Mediterraneanes Series seminaries. 17, 1992, 6774.

Youssef, M.K. (1992). Productive performance of purebred and crossbred rabbits. M.Sc. Thesis, Faculty of Agriculture at Moshtohor, Zagazig University, Banha Branch, Egypt. 


$$
\text { الملخص العربي }
$$

هدفت الدراسة الحالية علي دراسة تأثنر التركيب الوراتي وموسم الميلاد وترتيب البطن على صفات الخلفة ووزن الجسم في خطين من الارانب خط ارانب الفي لاين (V-line) وخط ارانب مشتهر (M-line) . نم استخدام عدد ستة آلاف وثلاثة مائه (6300 ارنب) في هذة الدراسة إنتجت من 300 أم و 100 ذكر لدراسة صفات وزن الجسم عند عمر 4 و 8 و 12 أسبوع من العمر. حجم الخلفة عند الميلاد (LSB) وحجم الخلفة عند الدان

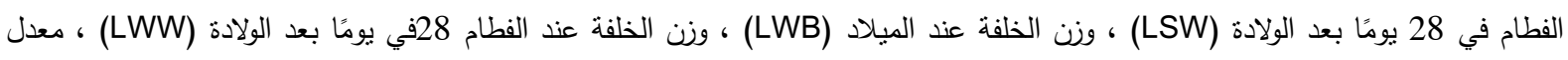

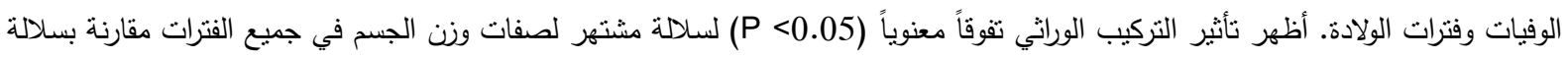

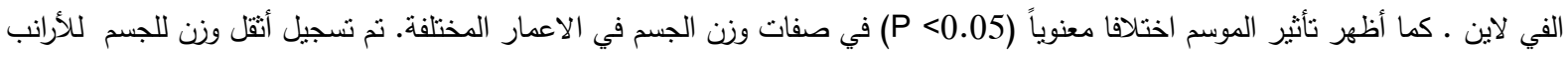

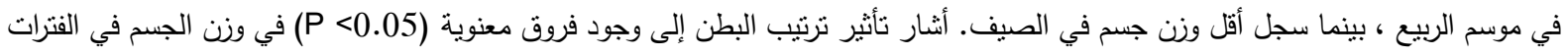

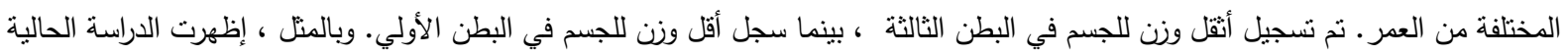

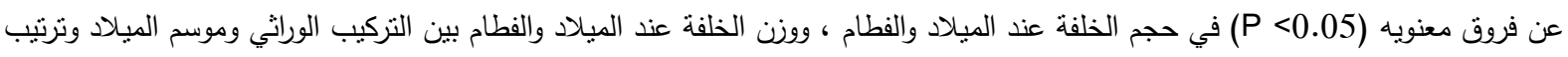

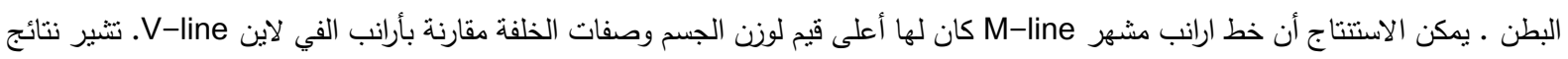

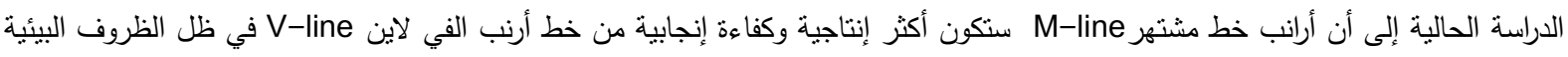

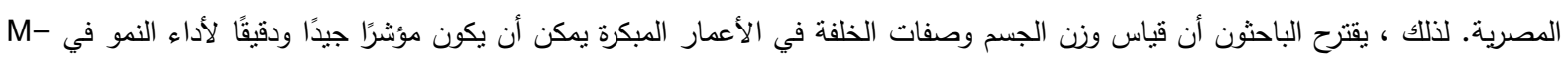

